\title{
RADIATION RISK MANAGEMENT WHEN HANDLING RADIOACTIVE SUBSTANCES AND MATERIALS
}

\author{
O.V. Mamontov, B.O. Malyk, O.V. Tokarieva \\ Kharkiv National University of Radio Electronics, Kharkiv, Ukraine \\ E-mail: olena.tokarieva@nure.ua
}

The system of personnel protection from ionizing radiation in laboratories and industrial premises, where they work with radioactive substances and materials has been considered. A logical scheme in the form of a tree of failures and mathematical expressions for calculating the reliability of the protection system are presented. The coefficients of the influence of individual elements on the reliability of the system are determined. A quantitative analysis of the coefficients of influence made it possible to identify the most significant and most unreliable elements ("weak links"). In order to replace the "weak links", a list of alternative elements and possible combinations of elements in the protection system has been compiled. Two risk management strategies are proposed. The first strategy involves minimizing the likelihood of failure of the protection system. The second is to minimize the cost of its operation. The possibility of achieving a positive effect has been demonstrated in both cases.

\section{INTRODUCTION}

The widespread use of radioactive substances in various branches of science and technology makes it necessary to improve the system of personnel protection against increased levels of ionizing radiation. This need ranges from the manufacture of products containing sources of ionizing radiation to dismantling, recycling or burial of sources [1].

Existing methods and means of staff protection ensure that acceptable standards are met in the workplace. Technical protection requirements are usually local. They apply to individual devices: ventilation units, screens, dosimetry devices or personal protective equipment. Today, there is no risk-reduction methodology that takes protection into account in a comprehensive manner. As a result, the maximum possible protective effect is not achieved and staff receive an excessive dose of radiation. Risk management, in the form of optimal decisions aimed at improving the radiation safety of personnel, therefore remains an important and urgent task.

Currently, a number of risk assessment techniques have been developed to determine their quantitative and qualitative characteristics for preventive security measures. Article [2] assesses the risk of mining technology systems using the standard FTA (fault tree analysis) method. The failures of the crushing and mixing plant in the crushing, mixing and conveyor systems are analysed. The management of reliability, maintenance and safety enhances the productivity of the overall process.

A similar approach is implemented in the work of [3] where the FTA is performed in order to determine critical factors, human errors and optimize the characteristics of the process. This work does not take into account the specific protection of human ionizing radiation. Nor do they provide specific information on improving the reliability of these systems. An improved approach is implemented in the works $[4,5]$ which use a combination of FMEA (Failure Mode and Effects Analysis) and FTA methods. The results of one method are the source data for the other. These methods also do not provide specific solutions to improve the reliability of systems for protection against high doses of radiation. Furthermore, these methods do not carry out analytical risk assessment of the system in order to identify and replace "weak links".

An approximate solution to this problem is given in work [6], where the effect of the individual element on the output of the system as a whole is evaluated. This solution makes it possible to calculate and improve the reliability of the system in the event of gradual operational failures. With this type of failure, the output parameter gradually exceeds the tolerance limit. These faults can be caused by various destabilizing factors (temperature, humidity, presence of aggressive environments, time, etc.). However, there is no reliability calculation for sudden operational failures, independent of the duration and conditions of the system's previous operation.

Work [2-6] does not contain optimal solutions aimed at protecting the personnel from increased levels of ionizing radiation. This problem is partially solved in Article [7], where the parameters of protective structures are optimized. However, there is no optimal decision to protect personnel when dealing with radioactive substances and materials.

The analysis of existing analogues showed that there is currently no analytical approach to identifying the most significant elements and "weak links" in the fault tree. The acquisition of such experience will be useful in the design and reconstruction of systems for the protection of human beings against ionizing radiation in the handling of radioactive substances and materials. This study will help to implement preventive security measures in the form of timely identification and replacement of unreliable parts of the system. This explains the relevance of a study aimed at analysing the risk in the tree failure of the human protection system against increased levels of ionizing radiation. Particular attention should be paid to the impact on the risk of individual elements of the system and the possibility of their replacement. 
The purpose of the publication is to confirm the possibility of optimizing personnel protection against ionizing radiation using various risk management strategies.

The protection system consists of certain technical elements. The risk of increased exposure of personnel to radiation is determined by the reliability of the elements of the system.

To achieve the goal, it is necessary to solve the following tasks:

- draw up a diagram of the personnel protection system in the premises for working with radioactive materials;

- compile a tree of faults (failures) and formulas for calculating the probability of the protection system failure;

- determine the influence of individual elements on the probability of failure and highlight the most significant elements;

-demonstrate the ability to manage risk by optimizing the selection of the most significant elements.

\section{SYSTEM FOR PROTECTING PERSONNEL FROM RADIATION EXPOSURE IN AN INDOOR ENVIRONMENT}

There are $n$ workplaces in the premises for work with radioactive materials (Fig. 1). Radiation safety of people is carried out by means of individual and collective protection. Personal protective equipment includes glove boxes 1, respirators, protective suits and personal dosimeters (see not shown in Fig. 1). Collective protection includes general intake ventilation, local exhaust ventilation and alarm system. The general intake ventilation consists of a flap (chimney) 2, a filter 3 , a fan 4 and an air duct 5. The local exhaust ventilation consists of an air duct 6 , a flap (chimney) 7 , a fan 8 and a filter (cleaning system) 9. The alarm system 10 includes a remote control, sensors and a loudspeaker.

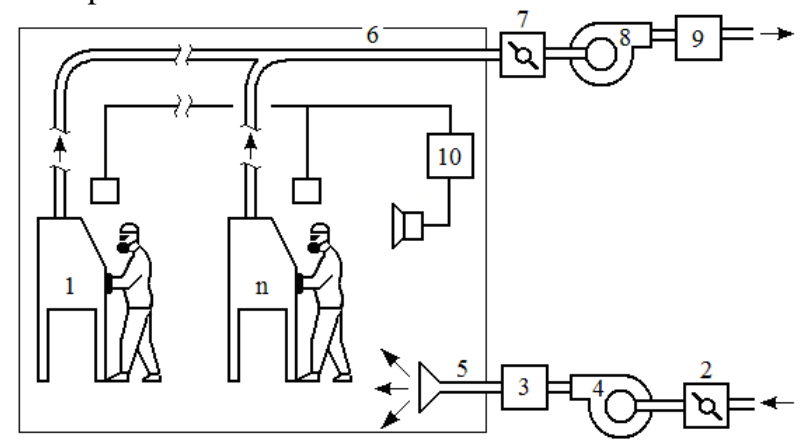

Fig. 1. Simplified functional diagram of the personnel protection system in a room with radioactive substances and materials

Normal ventilation involves the simultaneous operation of a general flow ventilation and local exhaust ventilation. Respirators and protective suits are mandatory but are designed to protect people against ventilation failure or rupture of gloves.

The correct protection system ensures the radiation safety of the personnel. The efficiency of the system is determined by the reliability of the elements. Each of these elements can be in two states: functional and defective.

In this paper, the protection system is taken in a simplified form. For example, the electrical network and switching elements are not considered. In case that the fans stop working due to an obvious network failure, safety can be ensured by evacuation, according to the labor protection instructions. Of particular interest are hidden failures, in which case it is impossible to ensure safety by organizational measures.

\section{CALCULATION OF THE PROTECTION SYSTEM FAILURE PROBABILITY}

The fault tree of the system for protecting people from increased levels of ionizing radiation is shown in Fig. 2. The composition and the structure of the tree is determined by the simplified functional diagram in Fig. 1.

The probability of failure of the protection system during the year is calculated using the formulas:

$$
\begin{gathered}
\mathrm{P}_{\mathrm{A}}=\mathrm{P}_{\mathrm{B}} \cdot \mathrm{P}_{\mathrm{O}} \\
P_{B}=P_{C} \cdot P_{D} \\
P_{C}=1-\left(1-P_{E}\right) \cdot\left(1-P_{F}\right) \\
P_{E}=1-\left(1-P_{G}\right) \cdot\left(1-P_{H}\right) \cdot\left(1-P_{I}\right) \cdot\left(1-P_{J}\right),(1) \\
P_{F}=1-\left(1-P_{K}\right) \cdot\left(1-P_{L}\right) \cdot\left(1-P_{M}\right) \cdot\left(1-P_{N}\right), \\
P_{O}=P_{R} \cdot P_{S} \\
P_{R}=1-\left(1-P_{T}\right) \cdot\left(1-P_{U}\right) \cdot\left(1-P_{V}\right) \\
P_{S}=1-\prod_{i=1}^{n}\left(1-P_{Q i}\right) \\
P_{T}=1-\prod_{i=1}^{n}\left(1-P_{W i}\right) \\
P_{U}=1-\prod_{i=1}^{n}\left(1-P_{X i}\right) \\
P_{V}=1-\prod_{i=1}^{n}\left(1-P_{Y i}\right)
\end{gathered}
$$

where $P_{A}-P_{Y}-$ respectively, the probability of undesirable events $A-Y$ during the year; $n$ - the number of jobs; $i$ - workplace number.

The probability of a system failure is a complex function of several variables. Obviously, different elements have different effects on the reliability of the system as a whole. To achieve this goal, it is necessary to search for the most influential elements and replace "weak links" at the stage of system design. 


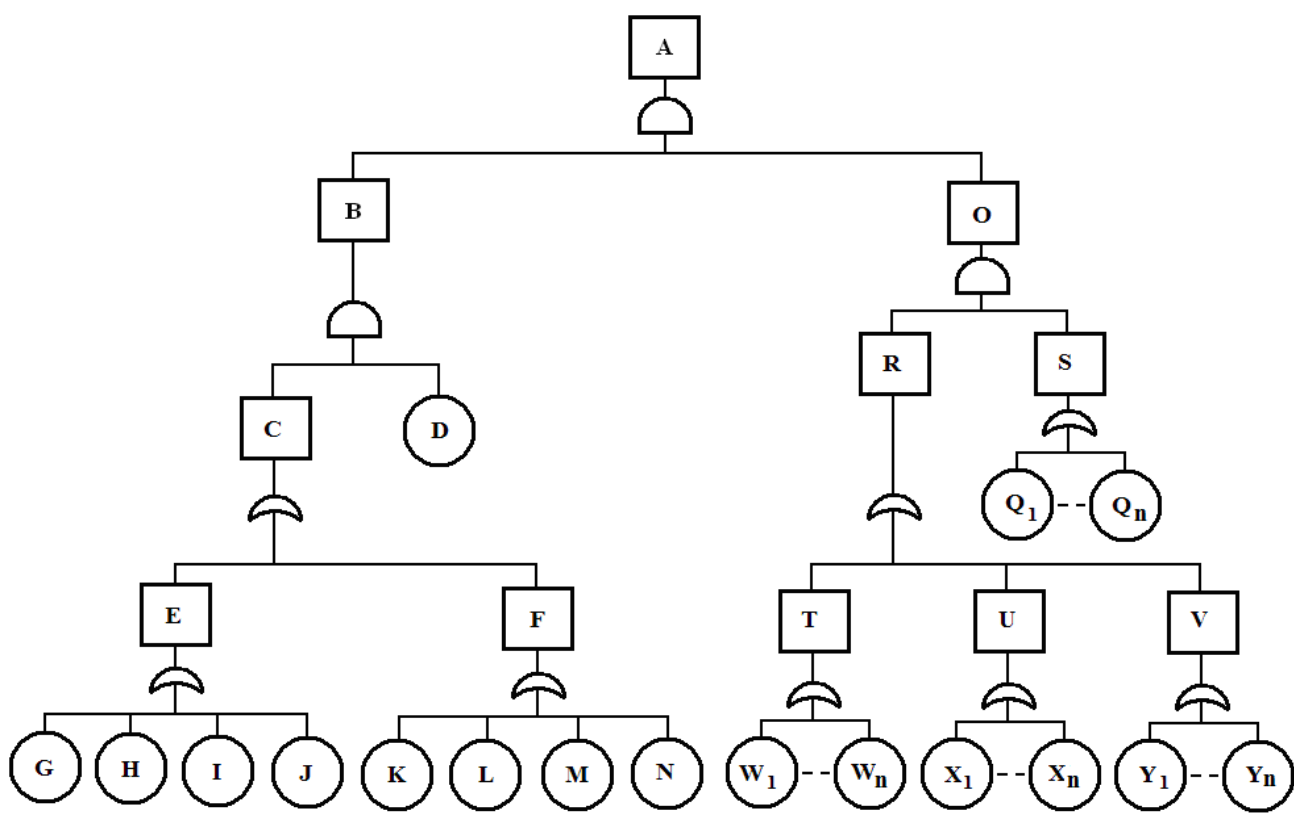

Fig. 2. Failure tree of the staff protection system against increased levels of ionizing radiation:

$A$ - Failure of the protection system; $B$ - Failure of the means of collective protection; $C$ - Failure of ventilation;

$D$-Failure of the alarm; $E$ - Failure of the general flow ventilation; $F$ - Failure of the local exhaust ventilation;

$G$ - Failure (jamming) of the flap 2; H - Failure (blocking) of the filter 3; I-Failure of the fan 4; J-Failure

(depressurization) of the air duct 5; $K$-Failure (depressurization) of the air duct 6; L-Failure (jamming) of the shutter 7; $M$ - the failure of the fan 8; $N$-the failure (clogging) of the filter 9; $O$ is the failure of the personal

protection means; $R$-Failure of at least one of the means: a pair of gloves, a suit, Respirator; $S$ - failure of at least one individual dosimeter; $Q_{n}$-failure of an individual dosimeter; $T$-failure of at least one pair of gloves;

$U$-failure of at least one suit; $V$-failure of at least one respirator; $W_{n}$-failure (rupture) of a pair of gloves;

$X_{n}$-suit failure (rupture); $Y_{n}$ - respirator failure (taking into account the planned replacement)

\section{DETERMINATION OF THE EFFECT OF INDIVIDUAL ELEMENTS ON THE PROBABILITY OF SYSTEM FAILURE}

This problem relates to mathematical analysis. It is proposed to assess the effect of individual elements on the probability of system failure by means of private derivatives of the formula:

$$
k_{Z}=\frac{\partial P_{A}}{\partial P_{z}}
$$

where $z$ - the number of the undesirable event (D, G-N, $\mathrm{Q}, \mathrm{W}-\mathrm{Y}) ; P_{A}-$ the probability of event $A$ during the year; $P_{z}-$ the probability of a corresponding event under $z$.

Finding the most influential elements will help to achieve the set goal by optimally replacing "weak links". For each "weak link", it is proposed to compile an additional list of alternative elements, having arranged them in a ranking sequence in order of the leading indicator.

The probability of an undesirable event numbered $z$ can be calculated using formula (13), due to the known values of the event intensity. The failure rates of standard products are usually determined by the manufacturers and are given in specifications (technical conditions). In the absence of these data, the customer enterprise can establish an incoming control. For nonstandard products, testing and special calculation procedures may be required.

$$
P_{z}(t)=1-e^{-t \cdot \lambda_{z}}
$$

where $\mathrm{t}$ - time; $\mathrm{h}, \lambda_{z}-$ the intensity $(1 / \mathrm{h})$ of an undesirable event (failure).

This value remains constant under the given operating conditions.

Tables 1 and 2 show the intensities of events $\mathrm{D}$, G-N, Q, W-Y. The intensities of events G, H, L, M, N, I are taken from reference books [8, 9]. The intensities of events $\mathrm{J}$ and $\mathrm{K}$ were calculated according to the method [10]. The event intensity $\mathrm{D}$ was calculated by the method [11]. Intensities of $\mathrm{W}-\mathrm{Y}$ events are taken from the source [12]. The protection system is operated in two-shift operation mode. The operating time of the system during the year is $4.8 \cdot 10^{3} \mathrm{~h}$. Number of working places -6 . Probability of failure of the protection system during the year calculated according to the formulae (1)-(11) taking into account these tables 1 is $4.9 \cdot 10^{-6}$.

Fig. 3 shows the characteristics of independent events D, G-N, Q, W-Y. As you can see, the diagrams in Fig. 3 do not have a general shape. From the diagram in Fig. 3,a it follows that the events H, J, M, N have the highest probability. From the diagram in Fig. 3,b, it follows that the most influential events under the given conditions are events D and Q. The "weakest" elements of the system are: alarms and individual dosimeters. 
Table 1

Initial data for calculating the probability of system failure

\begin{tabular}{|c|c|c|c|c|}
\hline $\begin{array}{c}\text { Event } \\
\text { designa- } \\
\text { tion } \\
\mathrm{z}\end{array}$ & $\begin{array}{c}\text { Event } \\
\text { intensity } \\
\lambda_{z}, 1 / \mathrm{h}\end{array}$ & $\begin{array}{c}\text { Influence } \\
\text { factors } \\
k_{z}\end{array}$ & $\begin{array}{c}\text { The } \\
\text { probability } \\
\text { of an event } \\
\text { within } \\
4.8 \cdot 10^{3} \mathrm{~h}, \\
P_{z}(t)\end{array}$ & $\begin{array}{c}\text { Probability } \\
\text { of the } \\
\text { protection } \\
\text { system } \\
\text { failure }\end{array}$ \\
\hline $\mathrm{D}$ & $3.1 \cdot 10^{-6}$ & $3.26 \cdot 10^{-4}$ & $1.5 \cdot 10^{-2}$ & \multirow{13}{*}{$4.9 \cdot 10^{-6}$} \\
\hline G & $4.2 \cdot 10^{-7}$ & $3.68 \cdot 10^{-5}$ & $2.0 \cdot 10^{-3}$ & \\
\hline $\mathrm{H}$ & $6.6 \cdot 10^{-6}$ & $4.89 \cdot 10^{-6}$ & $3.1 \cdot 10^{-2}$ & \\
\hline I & $5.6 \cdot 10^{-6}$ & $3.77 \cdot 10^{-5}$ & $2.7 \cdot 10^{-2}$ & \\
\hline J & $3.5 \cdot 10^{-7}$ & $3.68 \cdot 10^{-5}$ & $1.7 \cdot 10^{-3}$ & \\
\hline $\mathrm{K}$ & $3.8 \cdot 10^{-7}$ & $3.68 \cdot 10^{-5}$ & $1.8 \cdot 10^{-3}$ & \\
\hline $\mathrm{L}$ & $4.2 \cdot 10^{-7}$ & $3.68 \cdot 10^{-5}$ & $2.0 \cdot 10^{-3}$ & \\
\hline M & $5.6 \cdot 10^{-6}$ & $3.77 \cdot 10^{-5}$ & $2.7 \cdot 10^{-2}$ & \\
\hline $\mathrm{N}$ & $6.6 \cdot 10^{-6}$ & $3.79 \cdot 10^{-5}$ & $3.1 \cdot 10^{-2}$ & \\
\hline Q & $8.4 \cdot 10^{-7}$ & $1.21 \cdot 10^{-3}$ & $4.0 \cdot 10^{-3}$ & \\
\hline W & $1.7 \cdot 10^{-6}$ & $2.24 \cdot 10^{-4}$ & $8.1 \cdot 10^{-3}$ & \\
\hline$X$ & $1.5 \cdot 10^{-6}$ & $2.24 \cdot 10^{-4}$ & $7.2 \cdot 10^{-3}$ & \\
\hline Y & $1.1 \cdot 10^{-6}$ & $2.24 \cdot 10^{-4}$ & $5.3 \cdot 10^{-3}$ & \\
\hline
\end{tabular}

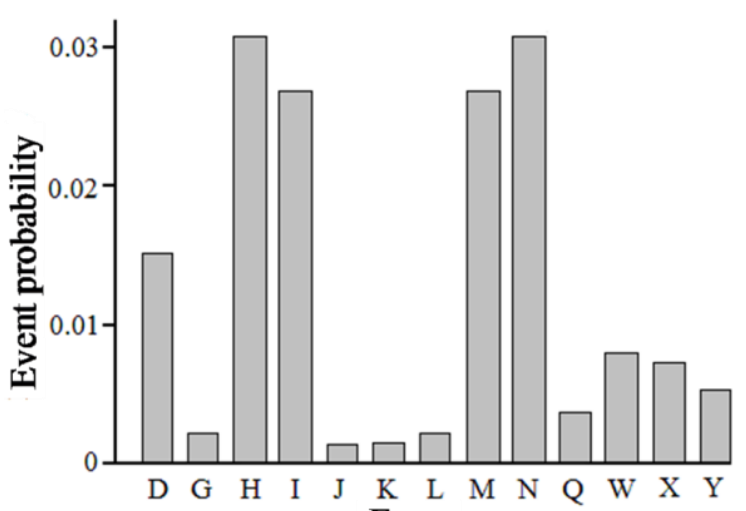

Event

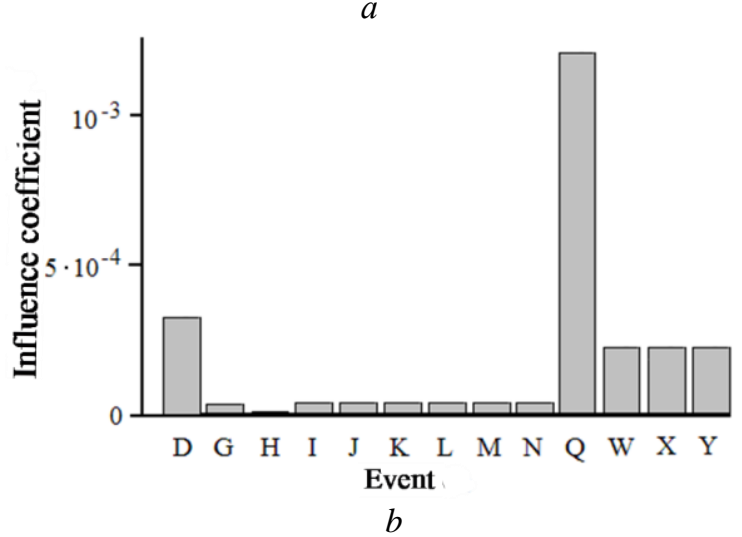

Fig. 3. Characteristics of independent events

$D, G-N, Q, W-Y: a-$ probability diagram;

$b$ - influence coefficients diagram

It is obvious that the characteristics in Fig. 3 are valid for the scheme in Fig. 1 for given values of the intensity of events (see Table 1).

\section{RISK MANAGEMENT OF RADIATION EXPOSURE}

It is proposed to manage the risk of radiation exposure by optimally replacing unreliable ("weak") elements with more reliable ones.

To improve the security of the system, it is proposed:

- preliminary find an alternative composition of the selected elements;

- make up possible combinations of the main and alternative elements;

- choose the most optimal combination of elements.

For alternative substitution, signalling and individual dosimeters are selected. Table 2 describes the event characteristics of D and Q for the initial and alternative composition of the selected elements. The signs $\left\langle{ }^{*} »\right.$ and $\langle * * »$ denote events corresponding to alternative elements.

Table 2

Characteristics of the initial and alternative composition of the selected elements

\begin{tabular}{|c|c|c|c|}
\hline $\begin{array}{c}\text { Event } \\
\text { desig- } \\
\text { nation, } \\
z\end{array}$ & $\begin{array}{c}\text { Event } \\
\text { intensity } \\
\lambda_{z}, 1 / \mathrm{h}\end{array}$ & $\begin{array}{c}\text { The } \\
\text { probability of } \\
\text { an event } \\
\text { within } \\
4.8 \cdot 10^{3} \mathrm{~h}, \\
P_{z}(t)\end{array}$ & $\begin{array}{c}\text { The cost per } \\
\text { item during } \\
\text { one year of } \\
\text { operation is } \\
\text { conv. un. }\end{array}$ \\
\hline $\mathrm{D}$ & $3.1 \cdot 10^{-6}$ & $1.5 \cdot 10^{-2}$ & 320 \\
\hline $\mathrm{D}^{*}$ & $2.2 \cdot 10^{-6}$ & $1.1 \cdot 10^{-2}$ & 480 \\
\hline $\mathrm{D}^{* *}$ & $1.8 \cdot 10^{-6}$ & $8.6 \cdot 10^{-3}$ & 650 \\
\hline $\mathrm{Q}$ & $8.4 \cdot 10^{-7}$ & $4.0 \cdot 10^{-3}$ & 120 \\
\hline $\mathrm{Q}^{*}$ & $7.3 \cdot 10^{-7}$ & $3.5 \cdot 10^{-3}$ & 150 \\
\hline $\mathrm{Q}^{* *}$ & $6.2 \cdot 10^{-7}$ & $3.0 \cdot 10^{-3}$ & 230 \\
\hline
\end{tabular}

Table 3 shows the various combinations of elements and the corresponding characteristics of the system The fourth column shows the total cost of the selected items for one year of operation $\left(4.8 \cdot 10^{3} \mathrm{~h}\right)$.

Table 3

Characteristics of the system

\begin{tabular}{|c|c|c|c|}
\hline $\begin{array}{c}\text { Combi- } \\
\text { nations } \\
\text { number }\end{array}$ & $\begin{array}{c}\text { Events } \\
\text { matching } \\
\text { combination } \\
\text { of selected } \\
\text { elements }\end{array}$ & $\begin{array}{c}\text { Probability } \\
\text { of systems } \\
\text { failure }\end{array}$ & $\begin{array}{c}\text { Total costs for } \\
\text { the number of } \\
\text { working places } \\
\text { (6), conv. un }\end{array}$ \\
\hline 1 & $\mathrm{D}, \mathrm{Q}$ & $4.9 \cdot 10^{-6}$ & 1040 \\
\hline 2 & $\mathrm{D}, \mathrm{Q}^{*}$ & $4.3 \cdot 10^{-6}$ & 1220 \\
\hline 3 & $\mathrm{D}, \mathrm{Q}^{* *}$ & $3.7 \cdot 10^{-6}$ & 1700 \\
\hline 4 & $\mathrm{D}^{*}, \mathrm{Q}$ & $3.6 \cdot 10^{-6}$ & 1200 \\
\hline 5 & $\mathrm{D}^{*}, \mathrm{Q}^{*}$ & $3.1 \cdot 10^{-6}$ & 1380 \\
\hline 6 & $\mathrm{D}^{*}, \mathrm{Q}^{* *}$ & $2.7 \cdot 10^{-6}$ & 1860 \\
\hline 7 & $\mathrm{D}^{* *}, \mathrm{Q}$ & $2.8 \cdot 10^{-6}$ & 1370 \\
\hline 8 & $\mathrm{D}^{* *}, \mathrm{Q}^{*}$ & $2.5 \cdot 10^{-6}$ & 1550 \\
\hline 9 & $\mathrm{D}^{* *}, \mathrm{Q}^{* *}$ & $2.1 \cdot 10^{-6}$ & 2030 \\
\hline
\end{tabular}

Fig. 4 shows the characteristics of the protection system according to the number of the combination of the selected elements: a - the diagram of security system failure probability; $b$ - cost diagram. 

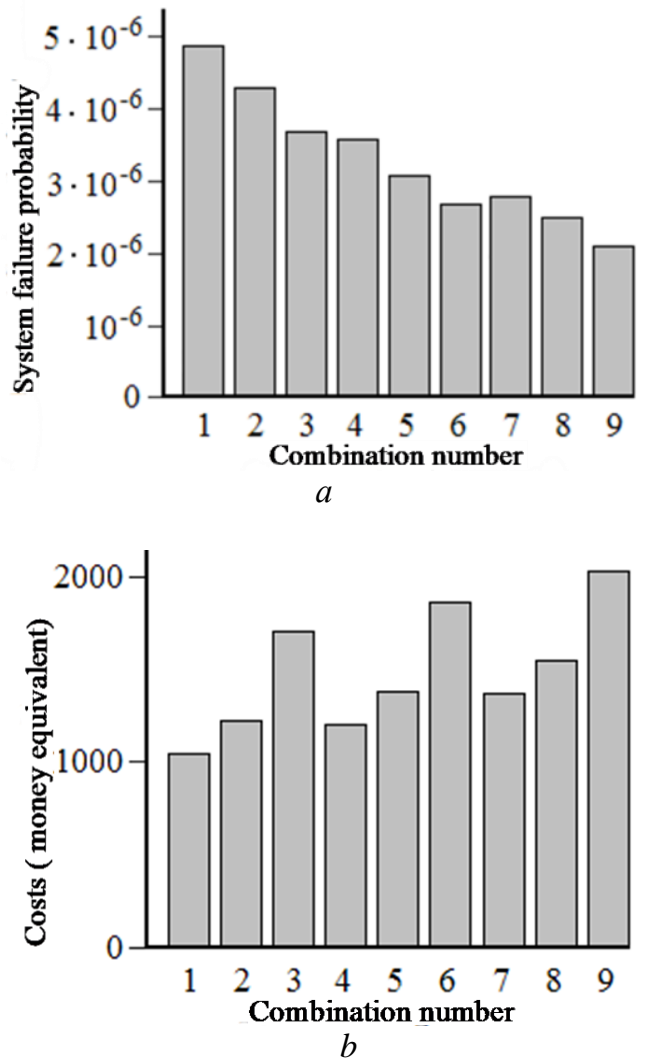

Fig. 4. Characteristics of the protection system depending on the combination of selected elements

The diagrams in Fig. 4 also have different shapes. This indicates the existence of various risk management strategies. Depending on the chosen strategy, each of the considered indicators can serve as both an objective function and a limiting condition.

The authors propose to use two risk management strategies in the considered conditions. The first strategy involves minimizing the risk. The maximum allowable costs are considered as limiting conditions. The second strategy is to minimize costs. The limiting condition is the minimum acceptable probability of system failure.

Obtained results confirm the possibility of managing the risk of radiation exposure using both proposed strategies. The solution with the smallest value of the objective function means choosing the optimal combination of elements. The choice of a risk management strategy is associated with a strategy for the development of production and available resources.

\section{EVALUATION OF THE OBTAINED RESULTS}

The analysis of the results shows that the lowest probability of system failure was obtained in combination 9 , with $2.1 \cdot 10^{-6}$. The highest probability was obtained with a combination of 1 , and was $4.9 \cdot 10^{-6}$. As a result of the study, this figure fell 2.33 times the maximum. The smallest total cost of the allocated items during the year was obtained with a combination of 1 , and amounted to 1040 (money equivalent) The highest cost was obtained with option 9, and amounted to 2030 (money equivalent). The economic effect was 990 (money equivalent).
With a small number of selected elements and their alternative substitution (up to 5 pieces), the problem can be solved by a complete selection of combinations. Increased number requires more sophisticated optimization methods and software.

\section{CONCLUSION}

As a result of the research, the following tasks were solved:

1. A diagram was drawn up and the composition of the elements of the personnel protection system in a room with radioactive substances and materials was determined.

2. Compiled a tree of failures and calculation formulas to determine the probability of system failure.

3. The influence of individual elements on the probability of system failure is determined, the most significant elements are highlighted. The use of private derivatives of the system failure probability function to find the most relevant elements has been confirmed.

4. Risk management has been proven by optimally selecting the most relevant elements. Two risk management strategies have been proposed for the conditions considered. The possibility of achieving a positive impact in both cases has been demonstrated.

\section{REFERENCES}

1. В.П. Машкович, А.В. Кудрявцев. Защзита от ионизирующих излучений: Справочник. М.: АП «Столица», 2013, 496 с.

2. Ali Nouri Gharahasanlou, Ashkan Mokhtarei, Aliasqar Khodayarei, Mohammad Ataei. Fault tree analysis of failure cause of crushing plant and mixing bed hall at Khoy cement factory in Iran // Case Studies in Engineering Failure Analysis. 2014, p. 33-38.

3. Roland-Iosif Moraru, Gabriel-Bujor Băbuţ. The use of fault tree in industrial risk analysis: a case study // Recent advances in industrial and manufacturing technologies: 1st WSEAS International Conference on Industrial and Manufacturing Technologies. 2013, p. 70-75.

4. N.A. Wessiani, F. Yoshio. Failure mode effect analysis and fault tree analysis as a combined methodology in risk management // IOP Conference. Series: Materials Science and Engineering. 2018, v. 337, p. 1-11.

5. C.-T. Liu, S.-L. Hwang, I.-K. Lin. Safety analysis of combined FMEA and FTA with computer software assistance-take Photovoltaic plant for example // IFAC Proc. 2013, v. 46, p. 2151-2155.

6. Zhai Guofu, Zhou Yuege, Ye Xuerong, Hu Bo. A method of multi-objective reliability tolerance design for electronic circuits // Chinese Journal of Aeronautics. 2011, p. 161-170.

7. O.V. Mamontov, B.O. Malyk, O.V. Tokarieva. Management of radiation safety by optimizing the parameters of protective structures // Problems of Atomic Scince and Tecnjlogy. 2020, N 2(126), p. 159164.

8. Учебный иентр Алексея Глазачева по надежности, теории вероятностей, статистике, комбинаторике, рискам и безопасности. Интенсивность отказов элементов: Справочник 
URL: https://areliability.com/intensivnost-otkazovelementov-spravochnik/areliability.com.

9. Г.Н. Антонов. Надежность систем энергетики и их оборудования: Справочник / Под ред. Ю.Н. Руденко. М.: «Энергоатомиздат», 1994, т. 1, $472 \mathrm{c}$.

10. В.Г. Китушин. Надежность энергетических систем. Технические основы: Уч. пособие. Новосибирск: Изд-во НГУ, 2003, ч. 1, 256 с.
11. В.В. Трифонюк. Надійність пристроїв промислової електроніки. Київ: «Либідь», 1993, c. 64 .

12. Freman.club: веб-сайт. URL: https://fireman.club/statyi-polzovateley/kostyumzashhitnyj-1-1-ttx-komplekt-xarakteristiki-poryadokodevaniya-i-snyatiya-ispolzovanie.

Статья поступила в редакциию 17.11.2020 2.

\title{
УПРАВЛЕНИЕ РИСКОМ РАДИАЦИОННОГО ОБЛУЧЕНИЯ ПРИ РАБОТЕ С РАДИОАКТИВНЫМИ ВЕЩЕСТВАМИ И МАТЕРИАЛАМИ
}

\author{
А.В. Мамонтов, Б.А. Малик, Е.В. Токарева
}

\begin{abstract}
Рассмотрена система защиты персонала от ионизирующих излучений в лабораториях и производственных помещениях, в которых работают с радиоактивными веществами и материалами. Приведены логическая схема в виде дерева отказов и математические выражения для расчета надежности системы защиты. Определены коэффициенты влияния отдельных элементов на надежность системы. Количественный анализ коэффициентов влияния позволил выявить наиболее значимые и ненадежные элементы («слабые звенья»). С целью замены «слабых звеньев» составлены перечень альтернативных элементов и возможные комбинации элементов в системе защиты. Предложены две стратегии управления риском. Первая стратегия предполагает минимизацию вероятности отказа системы защиты. Вторая минимизацию затрат на ее эксплуатацию. Продемонстрирована возможность достижения положительного эффекта в обоих случаях.
\end{abstract}

\section{УПРАВЛІННЯ РИЗИКОМ РАДІАЦИЙНОГО ОПРОМІНЕННЯ ПРИ РОБОТІ З РАДІОАКТИВНИМИ РЕЧОВИНАМИ І МАТЕРІАЛАМИ}

\section{О.В. Мамонтов, Б.О. Малик, О.В. Токарєва}

Розглянуто систему захисту персоналу від іонізуючого випромінювання в лабораторіях і виробничих приміщеннях, в яких працюють з радіоактивними речовинами та матеріалами. Наведено логічну схему у вигляді дерева відмов і математичні вирази для розрахунку надійності системи захисту. Визначені коефіцієнти впливу окремих елементів на надійність системи. Кількісний аналіз коефіцієнтів впливу дозволив виявити найбільш значущі і ненадійні елементи («слабкі ланки»). 3 метою заміни «слабких ланок» складено перелік альтернативних елементів і можливі комбінації елементів у системі захисту. Запропоновано дві стратегії управління ризиком. Перша стратегія передбачає мінімізацію ймовірності відмови системи захисту. Друга - мінімізацію витрат на їі експлуатацію. Продемонстровано можливість досягнення позитивного ефекту в обох випадках. 